Indonesian Journal of Global Health Research

Volume 1 Number 1, November 2019, pp. 59 - 72

e-ISSN 2715-1972; p-ISSN 2714-9749

http://jurnal.globalhealthsciencegroup.com/index.php/IJGHR

\title{
KOREAN DRAMA ADDICTION AND THE QUALITY OF SLEEP OF INDONESIAN STUDENTS
}

\author{
Eka Malfasari",Rizka Febtrina, Rina Herniyanti, Elsi Manda Utari \\ Nursing Program, STIKes Payung Negeri Pekanbaru, Jln Jendral, Labuh Baru Timur, Payung Sekaki, \\ Labuh Baru Tim, Kec. Pekanbaru Kota, Kota Pekanbaru, Riau, Indonesia 28156 \\ *mizzeka18@gmail.com
}

\begin{abstract}
The current phenomenon is about the addiction of korean drama which has an impact on the quality of students sleep, because students who like korean drama often forget the time to rest and feel curious about of each episode. Sleep is a besic need that must be fulfilled by every individual in order to carry out daily activities properly. The purpose of this research is to find out the relationship between korean drama addiction and the quality of studen's sleep in STIKes Payung Negeri Pekanbaru. This study was quantitative research with a cross sectional design. The sample of this research as much as 246 students STIKes Payung Negeri Pekanbaru from D3 Midwifery study program as much as 38 students, D3 Nursing as much as 31 students, S1 Nursing as much as 144 students and Public Health S1 as much as 33 students with technique sampling that is stratified random sampling. The instrument of this research used questionnaire compiled by the researchers with 25 statement items obtained from the validity test $r$ result $>\mathrm{r}$ table $(0,602>0,361)$ and the reliability test result are obtained 0,968 . While the sleep quality of questionnaire using Pittsburgh Sleep Quality Indeks (PSQI) which has been translated into indonesian the result of the validity test are obtained $0,365>0,361$ and reliability 0,741 , then the data analysis is tested using chi square. The result of this research found that the majority of students were not addicted to korean drama as much $124(50,4 \%)$ and the majority of poor students sleep quality is $181(73,6 \%)$. The result of this research indicate that there is no relationship between korean drama addiction and quality sleep of studen's STIKes Payung Negeri Pekanbaru with p value 0,429>0,05.
\end{abstract}

Keywords: addicted to korean drama, sleep quality

\begin{tabular}{|c|c|c|}
\hline $\begin{array}{c}\text { First Received } \\
28 \text { September } 2019\end{array}$ & $\begin{array}{c}\text { Revised } \\
06 \text { November } 2019 \\
\end{array}$ & $\begin{array}{c}\text { Accepted } \\
15 \text { November } 2019\end{array}$ \\
\hline $\begin{array}{c}\text { Final Proof Received } \\
20 \text { November } 2019\end{array}$ & & $\begin{array}{c}\text { Published } \\
30 \text { November } 2019 \\
\end{array}$ \\
\hline
\end{tabular}

\section{INTRODUCTION}

One of the causes of sleep quality problems is that they are addicted to watching Korean dramas (Drakor). The results of a survey conducted by Nielsen Korea on the highest viewer ratings in 2018 found that drama Return ranked first as the most watched drama of $17.4 \%$ with a peak reaching $20.1 \%$ (Adijaya, 2018). Korean television drama series shows the most television in young women in Semarang, with a range of 20 years of age as much as $36 \%$, and based on the level of education of adolescent girls who sit on lectures as much as $80 \%$ (Putri, 2013).

In Pekanbaru, it was found that 23 (100\%) of SMP 13 Pekanbaru students watched Korean drama with an intensity of watching $>6$ episodes a day (Adita, Rosmawati, \& Jacob, 2018). As a result of being addicted to watching Korean dramas, it makes individuals forget time because they feel challenged to spend every episode, then the 
other effects of addiction to Korean drama will make a person's activities less varied because they are only busy on Korean dramas including holidays, individuals continue to think about Korean dramas all day, then as many as $50 \%$ feel uneasy if they don't watch Korean dramas, don't focus on studying and want to go home quickly to watch Korean dramas, as many as $40.90 \%$ of individuals repeat watching Korean dramas after a long time stopping, and cause someone to become a private person because spend more time watching Korean drama than hanging out with family, friends and the surrounding environment (Oktadianti, Umari, \& Jacob, 2018).

Individuals who are addicted to Korean drama will use the time that should be used to sleep by watching Korean drama, this will make the rest and sleep time delayed which can result in individuals experiencing poor sleep quality (Adita et al., 2018). The results of a preliminary study of interviews on 12 February 2019 conducted with 10 undergraduate students of Nursing at STIKes Payung Negeri found that 8 students like to watch Korean dramas staying up late because episodes of Korean dramas are always intriguing, then 2 students say sleeping on time and not staying up late because it can still connect Korean drama the next day.

Interviews with midwifery D3 students conducted on 8 students found as many as 6 people liked Korean drama and watched before going to sleep so that sleep was not timely due to staying up late watching, then only 2 people said they did not particularly like Korean drama and always slept on time. From the foregoing it can be concluded that there are sleep quality disorders due to watching Korean dramas, but there are also students who always watch Korean dramas but their sleep quality is not disturbed. Therefore the researcher wants to see if there is a relationship between addiction to Korean drama and the quality of student sleep

\section{METHOD}

This research is a quantitative research with cross sectional design. The cross sectional design was used to examine how the relationship between Korean drama addiction and the sleep quality of STIKes umbrella students in Pekanbaru, where data collection was carried out at one time. The population in this study were students who were active in Pekanbaru State Umbrella STIKes, amounting to 683 students in 2019. Samples in this study were 246 students of Pekanbaru State Umbrella STIKes from the D3 Midwifery Study Program, D3 Nursing, S1 Nursing and S1 Public Health with sampling techniques namely stratified random sampling.

This research instrument uses a Korean drama addiction questionnaire compiled by researchers with aspects of Korean drama addiction such as salience, mood modification, withdrawal symptoms, tolerance, conflict and relapse as many as 25 statement items. This questionnaire consists of positive statements (favorable) and negative statements (unfavorable). This questionnaire uses a Likert scale with an alternative answer that is always, often, sometimes, almost never and never. The Korean drama addiction questionnaire has been tested for validity and reliability tests on 09-10 May 2019 at STIKes Hangtuah Pekanbaru with 30 respondents. The results of the questionnaire validity test obtained as many as 25 valid statements because the value of $r$ arithmetic $>r$ table that is with a range of $r$ arithmetic values $0.602-0.868>0.361$. The 
reliability test results obtained $\mathrm{r}$ alpha 0.968 , then the statement is reliable because $\mathrm{r}$ alpha> $\mathrm{r}$ table is $0.968>0.361$.

The questionnaire for sleep quality uses the Pittsburgh Sleep Quality Index (PSQI) which consists of seven components namely subjective sleep quality, sleep latency, sleep duration, sleep efficiency, sleep disturbance, use of sleeping pills and dysfunction of activities during the day. This PSQI has been translated into Indonesian and validity tests have been conducted on 30 respondents in the Ratnasari study (2016). The results show that all the questions in the PSQI measuring instrument are valid, with the results of the research validity test that is $\mathrm{r}$ count $>\mathrm{r}$ table $(0.365-0.733>0.361)$, then the reliability test obtained is entirely reliable with a value of 0.741 which is a high reliable criterion. Data analysis using univariate and bivariate analysis with chi square statistical tests, because the data of the independent variables and the dependent variable are equally categorical with a degree of confidence $\alpha=0.05$.

\section{RESULTS}

Tabel 1.

Age distribution among students $(\mathrm{n}=246)$

\begin{tabular}{lllll}
\hline Variabel & Mean & Median & Min-Mak & Standar Deviasi \\
\hline Age & 20,18 & 20,00 & $18-25$ & 1,313 \\
\hline
\end{tabular}

In table 1 it can be seen that the average age of the respondent is 20.18 years, the median of the age of the respondent is 20 years and the standard deviation is 1,313 years. The youngest age is 18 years and the oldest age is 25 years.

Tabel 2.

Distribution of student's gender $(\mathrm{n}=246)$

\begin{tabular}{lccc}
\hline & Gender & $\mathrm{f}$ & $\%$ \\
\hline Girl & 221 & 89,8 \\
Boy & 25 & 10,2 \\
\hline
\end{tabular}

In table 2 it can be seen that the respondents with the most frequency are 221 women $(89.8 \%)$ respondents and for the frequency of men $25(10.2 \%)$ respondents

Tabel 3.

Distribution based of study program $(n=246)$

\begin{tabular}{lcc}
\hline Program & f & $\%$ \\
\hline Midwifery diploma three & 38 & 15,4 \\
Nursing diploma three & 31 & 12,6 \\
Bachelor of public health & 33 & 13,4 \\
Bachelor of nursing & 144 & 58,5 \\
\hline
\end{tabular}

In table 3 it can be seen that the majority of respondents with Nursing S1 study programs were $144(58.5 \%)$ respondents. Whereas midwifery diploma $38(15.4 \%)$ respondents, Nursing diploma $31(12.6 \%)$ respondents and Bachelor of Public Health 33 $(13.4 \%)$ respondents. 
Tabel 4.

Distribution of korean drama addiction of students $(n=246)$

\begin{tabular}{lcc}
\hline \multicolumn{1}{c}{ Korean Drama Addiction } & f & $\%$ \\
\hline Not Addictive & 124 & 50,4 \\
Addictive & 122 & 49,6 \\
\hline
\end{tabular}

In table 4 it can be seen that the majority of respondents who are not addicted to Korean dramas are $124(50.4 \%)$ respondents, and the minority of respondents who are addicted to Korean dramas are $122(49.6 \%)$ respondents.

Tabel 5

Distribution of sleep quality frequency of students $(n=246)$

\begin{tabular}{lcc}
\hline \multicolumn{1}{c}{ Quality of Sleep } & f & $\%$ \\
\hline Good & 65 & 26,4 \\
Poor & 181 & 73,6 \\
\hline
\end{tabular}

In table 5 it can be seen that the majority of respondents 'sleep quality is poor as many as $181(73.6 \%)$ respondents, and the minority of respondents' sleep quality is good as many as $65(26.4 \%)$ respondents

Tabel 6

Relationship between korean drama addiction and student sleep quality $(\mathrm{n}=246)$

\begin{tabular}{lcccccccc}
\hline \multirow{2}{*}{$\begin{array}{c}\text { Korean Drama } \\
\text { Addiction }\end{array}$} & \multicolumn{3}{c}{ Quality of Sleep } & \multicolumn{2}{c}{ Total } & \multirow{2}{*}{$\begin{array}{c}\text { G } \\
\text { value }\end{array}$} & OR \\
\cline { 2 - 6 } & f & $\%$ & f & $\%$ & f & $\%$ & & \\
\hline Not Addictive & 36 & 29 & 88 & 71 & 124 & 100 & 0,429 & 1,312 \\
\hline Addictive & 29 & 23,8 & 93 & 76,2 & 122 & 100 & & $(0,742-2,318)$ \\
\hline
\end{tabular}

In table 6 it can be seen that the relationship between Korean drama addiction and the sleep quality of the students of STIKes Payung Negeri Pekanbaru with 246 respondents shows that students who are not addicted to Korean drama with good sleep quality are $36(29.0 \%)$ respondents, and students who are not addicted to drama Koreans with poor sleep quality were $88(71.0 \%)$ respondents. While students who were addicted to Korean dramas with good sleep quality were 29 (23.8\%) responsive, and students who were addicted to Korean dramas with poor sleep quality were 93 (76.2\%). Chi square statistical test results obtained a p value of 0.429 and a significance value greater than $5 \%(\mathrm{p}=0.429>0.05)$ and the results obtained that $\mathrm{H} 0$ is accepted and $\mathrm{Ha}$ is rejected, it can be concluded that there is no relationship between Korean drama addiction and sleep quality Pekanbaru State Umbrella STIKes students. From the results of the analysis also obtained the value of $\mathrm{OR}=1.312$, meaning that students who are not addicted to Korean drama have a chance of 1,312 times to get good sleep quality compared to students who are addicted to Korean drama.

\section{DISCUSSION}

The results of this study the average age of respondents was 20.18 years, for the youngest age is 18 years and the oldest age is 25 years. This is in line with Putra's research (2012) that early adulthood shows that individuals who experience loneliness have a role in the tendency of addiction to a behavior. In the early adult phase the individual will experience physical and psychological changes. Moving the adolescent phase into early adulthood requires a lot of adjustment to new life patterns and new 
social expectations, and in this early adult phase it is expected that individuals make self-adjustments independently (Hurlock in Putra, 2012).

Research by Marjosy, Kinasih, Andriani, \& Lisa, (2013) states that early adults have difficulty establishing good relationships with others due to the low social skills possessed by these early adults, so individuals will experience a tendency to become addicted to social networking sites. and others. Research Putri, (2018) also mentioned that early adolescents who are addicted to social media will affect their interpersonal communication.

This research shows that the most respondents are women. This is in line with Islamiyati's research (2017) that women prefer Korean dramas because they see male figures displayed in Korean dramas from a physical perspective such as being handsome, tall and athletic as well as being faithful and caring. Women also have unique feelings, this is because women more often express their feelings and have a great desire to always express about themselves (Ariani, Elita, \& Zulfitri, 2009). But for sleep quality Nurdilla et al., (2018) stated in his research that men are also prone to experience online gaming addictions that can affect their sleep quality, because addiction can lead to forgetfulness with rest and sleep.

Research Khasanah \& Hidayati, (2012) states that sex can also affect a person's sleep quality, women experience poor sleep quality due to a decrease in the hormones progesterone and estrogen so that anxiety, anxiety and emotions appear that can cause sleep disturbances. Researchers concluded that from the respondents surveyed the majority of women preferred Korean dramas over men, women preferred Korean dramas because Korean dramas made viewers feel carried away and fantasized of having a partner like those in Korean dramas. Whereas for the quality of sleep women can experience poor sleep quality because staying up late with marathons watching Korean dramas to spend every episode, while men watching Korean dramas are not too marathons to finish episodes, men can also experience poor sleep quality due to activities others like playing online games, surfing the internet, and hanging out with friends.

In this study the majority of respondents were in the Nursing S1 Study Program. This is in line with Sulastri's (2015) research that the nurse profession is a profession that is highly needed in medical personnel where nurses are a noble job and have great job opportunities. Basuki's research, (2015) states that D3 Nursing students experience a lot of work with their lectures such as making assignments, field practices, laboratory practices and organizational activities. Whereas Pitaloka et al., (2015) stated that S1 Nursing has class schedules from morning to evening, students also experience poor sleep quality due to college assignments, gadget usage, etc.

Nursing Diploma Three (D3) Education produces graduates who have competence as executors of nursing care for D3 Nursing patients and nurses working in the room. Whereas professional nursing education must at least go through the Bachelor of Nursing (S1) stages and also professional education which aims to produce nurses to have the ability to be professional nurses at the first level, S1 nurses who have taken professions have a level of more than D3 nursing because S1 nursing does not only 
provide care nursing but able to do management. Quality nurses are synonymous with professional nurses and qualified nurses are able to provide services in accordance with professional nursing standards that can be accepted by patients. (Sustainable, 2014).

The majority of respondents as many as 124 (50.4\%) were not addicted to Korean drama, meaning that more than half of the students of STIKes Payung Negeri Pekanbaru as respondents did not experience addiction to Korean drama. This is different from Sari, Rosmawati, \& Jacob's (2018) research that individuals who experience low Korean drama addiction have good character values. The results of the study are based on aspects of Korean drama addiction, namely salience, mood modification, withdrawal symptoms, tolerance, conflict, relapse.

From all aspects of Korean drama addiction, it is found that the aspect of tolerance produces the highest score compared to other aspects. In the aspect of salience, it was found that in this case the respondent forgot about the time while watching Korean drama, which was the majority balanced between forgetting time and not when watching Korean drama as many as 91 (37\%), then respondents who spent more time watching Korean drama than other activities the majority answered that they had never done that as many as $105(42.7 \%)$. Respondents who dreamed about Korean drama while sleeping, the majority answered that they had never experienced this, namely 156 (63.4\%). Then the respondents who think of Korean dramas every day the majority of respondents have never experienced it as much as 140 (56.9\%). Research by Putri et al., (2018) explained that in the aspect of salience, respondents took more time to watch Korean dramas, respondents imagined to be able to watch the latest Korean dramas, felt the time passed quickly while watching Korean dramas, hoping Korean dramas would become real. Research Oktadianti et al., (2018) mentions the aspect of salience or dominance of the activity of watching Korean drama series in the mind and behavior that is $50 \%$ think about Korean drama all day long.

In the aspect of mood modification, the majority of respondents who felt excited when watching Korean dramas stated that they were balanced or sometimes as many as 94 (38.2\%), respondents who were carried away (baper) when watching Korean dramas, the majority who stated that they were always 70 (28, 5\%). Respondents who chose to watch Korean drama to steer themselves away from the majority's problem stated that it was balanced or was sometimes done by $78(31.7 \%)$. Then respondents who felt Korean drama was the best way to relieve stress the majority stated balanced or sometimes done as much as $83(33.7 \%)$. Research Oktadianti et al., (2018) mentions that in the aspect of mood modification respondents get pleasure when watching Korean dramas and watching Korean dramas to escape from problems as much as $50.09 \%$.

Putri et al., (2018) stated that respondents felt excited when watching Korean dramas, felt immersed in the story, watched Korean dramas to improve mood, and divert attention from the problems at hand. In the aspect of withdrawal symptoms, the majority of respondents who felt uneasy if they didn't watch Korean dramas in a day said there were never 109 (44.3\%). The majority of respondents who were upset if they didn't watch Korean dramas stated that they had never been 136 (55.3\%). Respondents who did not focus on doing activities if they did not complete each episode of Korean drama stated the majority had never experienced it as many as $130(52.8 \%)$. Then the 
respondents who did not concentrate while studying if they had not completed all the episodes of Korean drama the majority said they had never experienced it as much as $146(59.3 \%)$.

The research of Putri et al., (2018) found that addiction to watching Korean dramas in the aspect of withdrawal symptoms was in the low category because respondents were never angry if they could not watch Korean dramas. However, the research of Oktadianti et al., (2018) states that respondents who stop watching Korean dramas feel unpleasant feelings and feel bad if they don't watch Korean dramas by $40.90 \%$. In the aspect of tolerance, respondents who were dissatisfied when watching Korean dramas were only 4 episodes, the majority of respondents said there had never been 91 (37.0\%). The majority of respondents who watched 16 episodes of Korean drama in a day (24 hours) stated that they had never done that as many as $149(60.6 \%)$. The majority of respondents who spent their days off watching Korean dramas stated that they were balanced or sometimes did so as much as 90 (36.6\%). Respondents who collected Korean dramas as a supply to continue watching Korean dramas stated that they had never done so much as 99 (40.2\%). Respondents who were impatient waiting for time to go home to college in order to watch Korean dramas, the majority answered, were never $126(51.2 \%)$.

The tolerance aspect in the research of Putri et al., (2018) found that respondents felt different satisfaction resulting in an increase in the duration of watching Korean dramas and the respondents had a large supply of Korean dramas to be watched next. Research Oktadianti et al., (2018) states that the activity of watching Korean drama has increased progressively over a period of time to get satisfaction, and the time to watch Korean drama is increasing. In the aspect of conflict, respondents spent more time watching Korean drama than gathering with family and the majority of friends answered that they had never done that as many as $141(57.3 \%)$. Respondents who were confused about choosing between college assignments or watching Korean dramas, the majority answered that they never understood it as much as 125 (50.8\%). Respondents ignored their friends who asked to talk while watching Korean dramas, the majority answered that they had never done that as many as 90 (36.6\%). Respondents who felt the interaction with friends was reduced because watching Korean dramas, the majority answered that they had never experienced it as much as $123(50.0 \%)$.

Research by Putri et al., (2018) found that the conflict aspect is in the medium category because respondents are often said to be alay by their friends, this is because respondents make watching Korean dramas a priority, until finally problems arise with friends due to lack of interaction caused by watching Korean drama While the research Oktadianti et al., (2018) found that as many as 50\% of respondents quarreled with others because it was too excessive in watching Korean dramas. In the relapse aspect, the majority of respondents who failed while trying to stop watching Korean dramas answered that they had never experienced it as much as $112(45.5 \%)$. Respondents were interested in watching again when there was an exciting new Korean drama even though they had stopped watching the majority, the majority answered that they had never done it as many as $74(30.1 \%)$. Respondents were curious again after stopping watching Korean dramas, the majority of them answered in balance or sometimes experienced it 
as much as $79(32.1 \%)$. Respondents returned to watch Korean drama after a long stop, the majority answered that they had never done that as many as $91(37.0 \%)$.

Research Oktadianti et al., (2018) found that the tendency to watch again after a long time not watching as much as $36.36 \%$. The research of Putri et al., (2018) states that respondents tend to have feelings to watch Korean dramas again after a long stop watching Korean dramas, this causes respondents to not be able to stop the habit of watching Korean dramas and these activities are always done repeatedly. The majority of STIKES Payung Negeri Pekanbaru students' sleep quality is poor. This is in line with research by Pitaloka et al., (2015) which revealed that poor sleep quality of students. Because seen from their activities, students have class schedules from Monday to Saturday which starts from morning to evening. The duration of student sleep is less than 8 hours because of delaying sleep time to complete college assignments.

The results of the study are based on sleep quality components, namely subjective sleep quality, sleep latency, sleep duration, sleep efficiency, sleep disturbance, medication use and activity dysfunction during the day. From the sleep quality component, sleep duration has the highest score which means that the respondent has problems sleeping with insufficient duration or duration of sleep. The component of drug use has the lowest score, meaning that not many respondents use drugs to help them fall asleep in the past month. In the subjective quality of sleep component in the last month the majority of respondents have a pretty good sleep quality of $136(55.3 \%)$, for subjective sleep quality very good $32(13.0 \%)$, poor as many as $60(24.4 \%)$, and very bad 18 (7.3\%). In contrast to the study of Pitaloka et al., (2015) which states the majority of students' sleep quality in the past week is bad.

The latency of sleep or individuals who have difficulty starting to sleep in the last month the majority of respondents have a score of 1-2 as many as 112 (45.5\%), for a score of 0 as much as $42(17.1 \%)$, a score of 3-4 as much as $76(30.9 \%)$ and scores 5-6 are $16(6.5 \%)$. Similarly, the study of Pitaloka et al., (2015) which states that students find it difficult to start sleeping and spend about 15-60 minutes in bed until finally they can fall asleep. According to Agustin in Thayeb, Kembuan, \& Khosama, (2015) states that the factors that influence a person is difficult to fall asleep are eating habits before bed and smoking habits that can increase sleep latency.

The duration of sleep or the length of sleep of respondents in the last month the majority of 5-6 hours as many as $106(43.1 \%)$, sleep duration> 7 hours as much as $38(15.4 \%)$, sleep duration of 6-7 hours as many as $74(30.1 \%)$, and sleep duration $<5$ hours are 28 (11.4\%). Research by Pitaloka et al., (2015) states that the majority of students have a duration or duration of sleep in the last week that is $<7$ hours. In contrast to the study of Thayeb et al., (2015) which states that a night service nurse has a sleep duration <5 hours this is due to the work profession of nurses who must be responsive in caring for patients, whereas the normal duration of sleep for adults is 7-8 hours / day.

The sleep efficiency of respondents in the last month the majority of $>85 \%$ by 183 (74.4\%), sleep efficiency by $75-84 \%$ by 39 (15.9\%), sleep efficiency by $65-74 \%$ by 14 $(5.7 \%)$, and sleep efficiency $<65 \%$ by $10(4.1 \%)$. Research Thayeb et al., (2015) also states that the majority of respondents have sleep efficiency $>85 \%$ by $38.46 \%$, this 
efficiency can be determined by comparing the actual sleep time with the length of time when in bed and multiplied by $100 \%$, if more than $84 \%$ then someone's sleep can be said to be efficient. Sleep disorders experienced by respondents in the past month such as waking up in the middle of the night or early morning, waking up to the bathroom, difficulty breathing comfortably, coughing, feeling cold, feeling overheated, having nightmares, feeling pain, other causes are playing cellphones (gadgets ), for college assignments, stress, etc., the majority of respondents who experience sleep disorders have a score of 1-9 as many as $139(56.5 \%)$, sleep disorders with a score of 0 as many as $9(3.7 \%)$, sleep disorders with a score of 10-18 as many as $84(34.1 \%)$ and sleep disorders with a score of 19-27 as many as 14 (5.7\%).

Research Thayeb et al., (2015) states that sleep disturbance can occur due to interference with circadian rhythms that cause shifts in the sleep rhythm cycle and wake rhythm. The use of drugs in the last month to help can fall asleep, the majority of respondents have never used drugs as many as 210 (85.4\%), the use of drugs once a week as many as 24 (9.8\%), the use of drugs 2 times a week as much as $10(4.1 \%)$, and the use of drugs 3 or more times a week as much as $2(0.8 \%)$. Research Thayeb et al., (2015) also states that most nurses who work at night do not use sleeping pills, this can be caused because nurses are health workers who understand that taking sleeping pills can have adverse effects. Activity dysfunction or disruption in daytime activities in the past month such as difficulty to stay awake, not sleepy in doing activities, problems in concentrating when the majority of respondents have a score of 1-2 as many as 124 $(50.4 \%)$, then a score of 0 as many as $40(16,3 \%)$, a score of 3-4 as many as 71 $(28.9 \%)$ and a score of 5-6 as many as $11(4.5 \%)$.

Pitaloka et al., (2015) states that students experience small to large problems in the past week, this can cause anxiety. Researchers concluded that more than half of STIKes Payung Negeri students who were respondents experienced poor quality. This is because they have hours or rest periods that are not met properly. If the problems experienced by respondents are not resolved properly it will result in lack of concentration when doing activities, easy to feel tired, excessive sleepiness during the day and vulnerable to disease.

Regarding the relationship between Korean drama addiction and the sleep quality of students of STIKes Payung Negeri Pekanbaru with 246 respondents, the results of calculations using the chi square statistical test showed that there was no relationship between Korean drama addiction and sleep quality of STIKes Payung Negeri Pekanbaru students indicated by the p value of 0.411>0 .05, which means $\mathrm{HO}$ is accepted and $\mathrm{Ha}$ is rejected. From the analysis also obtained OR value $=1.328$ which means that students who are not addicted to Korean drama have only 1.328 times the chance of getting good sleep quality. This is supported by the research of Sari et al., (2018) that a person can be said to be addicted to watching Korean drama or cannot be seen in aspects of Korean drama addiction such as salience, mood modification, conflict, tolerance, withdrawal symptoms and relapse.

Research Oktadianti et al., (2018) mentions that individuals who have self control in addiction to watching Korean drama do not force themselves to watch if they are sick, 
because Korean drama is not contrary to their beliefs, and individuals always think before they act and choose to complete one task before Other tasks pile up.

Research by Adita et al., (2018) states that one of the effects of individuals who are addicted to Korean drama is consumerism that can ignore social and environmental relations. Symptoms found in this research are updating information about Korean dramas, spending time off watching Korean dramas on laptops, getting ridicule from other students who don't like Korean dramas. The effect of Korean drama shows is the influence of Korean actors and artists in terms of clothing styles and hairstyles (Darliana, 2013).

This study is different from the research of Putri et al., (2018) because the research subjects are individuals who watch Korean dramas $>6$ episodes in one watch, then the addiction categories in their research are low, medium and high categories. Then individuals who are addicted feel happy while watching Korean dramas, are confused about choosing other activities besides watching Korean dramas because of their daily activities by watching Korean dramas and they feel uneasy when not watching Korean dramas. This is in line with research Herpina \& Amri (2017) which states that the opportunity for students when watching Korean drama is at night and also on holidays. Where this Korean drama has the advantage that there is no advertisement and showtimes. This made students initially only watch two episodes but instead could not stop watching until the drama was finished. Automatically this will make a fan of Korean drama can sleep less and feel sleepy during lecture hours, because Korean dramas are always thought about every day as a result when returning home continue to Korean drama until there is no time to rest and sleep.

In this study students experienced poor sleep quality even though they were not addicted to Korean dramas. In the study of Pitaloka et al., (2015) states that poor sleep quality can be experienced by students because of various causes such as insufficient sleep due to delaying sleep, activities carried out before going to sleep, consuming caffeine which can cause difficulty sleeping, excessive use of gadgets before sleep, uncomfortable sleeping conditions and improper temperature.

\section{CONCLUSION}

Researchers concluded that students who are addicted to Korean drama can affect their sleep quality, but students who are not addicted to Korean drama can also experience poor sleep quality due to other activities carried out that disrupt rest and sleep. This activity is certainly carried out before going to sleep and can take up hours of sleep which will result in poor sleep quality, therefore students need to improve self-control so as not to sleep late and learn to discipline to regulate sleep hours so that the quality of sleep becomes good and adequate sleep rest, because with a good quality of sleep will make the concentration of students when studying better which can improve memory in the mind, and more focused in carrying out daily activities

\section{REFERENCES}

Adijaya, I. (2018). 10 Drama dengan Rating Tertinggi Tahun 2018 Versi Nielsen Korea, Kamu Sudah Nonton? Retrieved February 27, 2019, from https://www.sumber.com/hiburan/berita-terkini-hiburan/sumber/10-dramadengan-rating-tertinggi-tahun-2018-versi-nielsen-korea,-kamu-sudah-nonton.html 
Adita, W. B., Rosmawati, \& Yakub, E. (2018). Perilaku Kecanduan Menonton Drama Korea dan Hubungan Sosial pada Siswa SMPN 13 Pekanbaru. JOM FKIP, 5(1), $1-15$.

Retrieved from https://jom.unri.ac.id/index.php/JOMFKIP/article/view/20439/19771

Ariani, M., Elita, V., \& Zulfitri, R. (2009). Hubungan Intensitas Penggunaan Jejaring Sosial Terhadap Kualitas Tidur Remaja di SMAN 3 Siak, 1-11. https://doi.org/10.1016/0378-7788(82)90008-1

Basuki, H. D. J. (2015). Gambaran Pola Makan Terhadap Risiko Gastritis pada Mahasiswa DIII Keperawatan di Universitas Muhammadiyah, 3(2), 54-67. Retrieved from http://eprints.umpo.ac.id/id/eprint/1253

Darliana. (2013). Pengaruh Tayangan Drama Korea Terhadap Perilaku Kaum Muda (Studi Kasus: Komunitas Pecinta Drama Korea Dan Kpop). Universitas Bina Nusantara, 9. Retrieved from https://thesis.binus.ac.id/Doc/WorkingPaper/20142-01881-MC WorkingPaper001.pdf

Diarti, E., Sutriningsih, A., \& Rahayu, W. (2017). Hubungan Antara Penggunaan Internet dengan Gangguan Pola Tidur Pada Mahasiswa PSIK UNITRI Malang. Nursing News, 2(3), 321-331. Retrieved from https://publikasi.unitri.ac.id/index.php/fikes/article/viewFile/656/528

Herpina, \& Amri, A. (2017). Dampak Ketergantungan Menonton Drama Korea Terhadap Perilaku Mahasiswa Ilmu Komunikasi Universitas Syiah kuala. Jurnal Ilmiah Mahasiswa FISIP Unsyiah, 2(2), 1-13. Retrieved from http://www.jim.unsyiah.ac.id/FISIP/article/viewFILE/2679/1599

Islamiyati, A. N. (2017). Drama Korea dan Khalayak (Penerimaan Perempuan Indonesia Terhadap Budaya dan Sosok Laki-laki yang ditampilkan dalam Tayangan Drama Korea), 1-29. Retrieved from http://etheses.uinmalang.ac.id/id/eprint/2617

Khasanah, K., \& Hidayati, W. (2012). Kualitas Tidur Lansia Balai Rehabilitasi Sosial "MANDIRI" Semarang. Jurnal Nursing Studies, 1(1), 189-196. Retrieved from http://ejournal-s1.undip.ac.id/index.php/jnursing

Lestari, T. R. P. (2014). Pendidikan Keperawatan: Upaya Menghasilkan Tenaga Perawat Berkualitas. Aspirasi, 5(1), 1-10.

Marjosy, U., Kinasih, A. D., Andriani, I., \& Lisa, W. (2013). Hubungan antara Keterampilan Sosial dan Kecanduan Situs Jejaring Sosial pada Masa Dewasa Awal. Proceeding PESAT (Psikologi, Ekonomi, Sastra, Arsitektur \& Teknik Sipil), 5, 78-84. Retrieved from https://media.neliti.com/media/publications/172566-IDhubungan-antara-keterampilan-sosial-dan.pdf

Nurdilla, N., Arneliwati, \& Elita, V. (2018). Hubungan Kecanduan Bermain Game Online dengan Kualitas Tidur Remaja. JOM FKp, 5(2), 120-126. Retrieved from https://jom.unri.ac.id/index.php/JOMPSIK/article/view/21007/20329 
Oktadianti, R., Umari, T., \& Yakub, E. (2018). Perilaku Kecanduan Menonton Drama Korea dan Self Control (Kontrol Diri) Siswa SMAN 7 Pekanbaru. JOM FKIP, 5(1), 1-14. Retrieved from https://jom.unri.ac.id/index.php/JOMFKIP/article/view/20229/19565

Permadi, A., \& Khusnal, E. (2017). Hubungan Perilaku Penggunaan Gadget dengan Kualitas Tidur pada Anak Usia Remaja di SMA Negeri 1 Srandakan Bantul. Unisa, 1-7. Retrieved from http://digilib.unisayogya.ac.id/id/eprint/2497

Pitaloka, R. D., Utami, G. T., \& Novayelinda, R. (2015). Hubungan Kualitas Tidur dengan Tekanan Darah dan Kemampuan Konsentrasi Belajar Mahasiswa Program Studi Ilmu Keperawatan Universitas Riau. JOM, 2(2), 1435-1443. Retrieved from https://jom.unri.ac.id/index.php/JOMPSIK/article/view/8317

Putra, D. R. (2012). Hubungan antara Kesepian dengan Kecenderungan Kecanduan Internet pada Dewasa Awal. Retrieved from http://etheses.uinmalang.ac.id/id/eprint/2617

Putri, D. (2013). Hubungan Intensitas Menonton Tayangan Drama Seri Korea di Televisi dan Motif Menonton Tayangan Drama Seri Korea di Televisi dengan Perilaku Berpakaian Remaja. Undip, 4(3), 1-2. Retrieved from http://fejournal.ilkom.fisip-unmul.ac.id.

Putri, R. Y., Rosmawati, \& Yakub, E. (2018). Kecanduan Menonton Drama Korea dan Perilaku Imitasi pada Siswa SMA Negeri 12 Pekanbaru. JOM FKIP, 5(1), 1-15. Retrieved from https://jom.unri.ac.id/index.php/JOMFKIP/article/download/20059/19398

Ratnasari, C. D. (2016). Gambaran Kualitas Tidur Pada Komunitas Game Online Mahasiswa Teknik Elektro Universitas Diponegoro. Retrieved from http://eprints.undip.ac.id/51197/1/BAB_1-3.pdf

Rosenberg, R., Czeisler, C. A., Gradisar, M., Hale, L., Harvey, A. G., \& Wolfson, A. R. (2011). Annual Sleep in America Poll Exploring Connections with Communications Technology Use and Sleep. National Sleep Foundation. Retrieved from https://www.sleepfoundation.org/press-release/annual-sleepamerica-poll-exploring-connections-communications-technology-use-and

Sari, D. F. (2015). Motif Menonton Drama Korea di Televisi oleh Remaja Surabaya. Commonline Departement Komunikasi, 4(1), 60-72. Retrieved from http://journal.unair.ac.id/download-fullpapers-comme465029b70full.pdf.

Sari, Y. P., Rosmawati, \& Yakub, E. (2018). Perilaku Kecanduan Menonton Drama Korea dan Nilai Karakter Siswa SMK Labor Binaan FKIP UNRI Pekanbaru. JOM FKIP, 5(2), 1-11. $\quad$ Retrieved from https://jom.unri.ac.id/index.php/JOMFKIP/article/download/20687/20012

Sidharta, B., Amir, N., Bastaman, T. K., \& Redayani, P. (2010). Dampak Insomnia Terhadap Kesehatan Tubuh. In Medicastore. Retrieved from http://medicastore.com/seminar/108/Dampak_Insomnia_Terhadap_Kesehatan_Tu buh.html 
Sulastri. (2015). Motivasi Mahasiswa Memilih Program Studi Ilmu Keperawatan Universitas Riau. JOM FISIP, 2(2), 1-15. Retrieved from https://media.neliti.com/media/publications/32654-ID-motivasi-mahasiswamemilih-program-studi-ilmu-keperawatan-universitas-riau.pdf

Thayeb, R. R. T. A., Kembuan, M. A. H. N., \& Khosama, H. (2015). Gambaran Kualitas Tidur Pada Perawat Dinas Malam Rsup Prof. dr. r. d. Kandou Manado. Jurnal E-Clinic (eCl), 3(3). Retrieved from https://ejournal.unsrat.ac.id/index.php/eclinic/article/view/10457/10043 
Indonesian Journal of Global Health Research, Vol 1 No 1, November 2019, pp. 39 - 46 Global Health Science Group 